\title{
The Effect of Tax Evaluation Trials and Community Social Views on Tax Evasion Practices
}

\author{
Lawe Anasta Suharmadi \\ Economics Faculty, Universitas Mercu Buana
}

\begin{abstract}
This research aims to determine the effect of Tax Payer of trust and Social Opinion to the Tax Evasion. The object of this research is Kebayoran Lama Traditional Market in South Jakarta. The research design used is causal research. The sampling technique used is accidental sampling. This study was conducted during the period January 2018 until May 2018 with a sample 100 people listed on is Kebayoran Lama Traditional Market in South Jakarta. The data used in this study is primary data obtained from spread of the questionnaire. Data analysis method used is panel data regression analysis method with the help of SPSS 21.0 software. The results of this study indicate that the Tax Payer of Trust have an effect on Tax Evasion of the company in Kebayoran Lama Traditional Market South Jakarta. However, that the Social Opinion have an effect too on Tax Evasion of the company in Kebayoran Lama Traditional Market South Jakarta.
\end{abstract}

Keywords : Tax Payer of Trust, Social Opinion, and Tax Evasion.

DOI: $10.7176 /$ RJFA/11-16-09

Publication date:August $31^{\text {st }} 2020$

\section{INTRODUCTION}

A. Background

The largest source of state funding recognized for almost all countries in the world is the taxation sector. In Indonesia, which is a developing country with the largest source of income, also through the taxation sector. The aim of taxation in this country is to increase income which will later be used to fund government needs and activities, reduce the inequality of distribution of one area to another, and to measure the level of private economic activity.

The state uses tax revenues to support development financing. Tax revenue is expected to continue to increase so that the country's development can run well. Increased tax revenue is achieved if an increase in the number of taxpayers occurs. Efforts to maximize tax revenue cannot rely solely on the role of the Director General of Taxes or tax officials, but the active role of the taxpayers is also needed. Given the importance of the role of taxes, the government in this case the Directorate General of Taxes has made various efforts to maximize tax revenues (Tryana 2013). A country in regulating the national economy must make the state budget for income and expenditure (APBN), Indonesia is no exception. One of the main sources of the Indonesian state budget is tax. At present 2/3 of state revenues come from taxes (Permatasari, 2013: 1). In Indonesia efforts to increase and optimize tax revenue are carried out through intensification and extensification of tax revenues. Tax evasion as a scheme minimizes tax owed by violating tax provisions such as by reporting part of sales or increasing costs fictitiously (Darussalam, 2009 in Agustiati (2011: 13)Tax evasion is an act that violates UUP, by submitting in the Annual Income Tax Return (understatement of income) on the one hand and or reporting overstatement of the deductions in others. A more severe form of tax evasion is if a taxpayer (WP) does not report his income (non-reporting of income) at all.

The treatment of tax evasion is influenced by various things such as tax rates too high, lack of information from tax authorities to taxpayers about their rights and obligations in paying taxes, lack of firmness of government in responding to fraud in paying taxes so that taxpayers have the opportunity to conduct tax evasion. Another tax evasion case occurred in 2016 where the Press Release of the Directorate General of Tax Ministry of Finance reported that at the West Kalimantan High Prosecutor's Office together with West Kalimantan Regional Police handed over a YLT initial suspect along with evidence to the Public Prosecutor at the Pontianak District Prosecutor's Office. The YLT suspect, an individual taxpayer registered at the Tax Service Office (KPP) of Pratama Pontianak, allegedly violated Article 39 paragraph (1) letter c of the UU KUP namely deliberately not submitting a Tax Return (SPT), during the 2010 tax year, with threats imprisonment for a minimum of six months and a maximum of four times the amount of tax payable that is not or is underpaid.

The value of losses on state revenues for these violations reached $\mathrm{Rp} 4.2$ billion.In the study of the practice of tax evasion involving parameters of taxpayer trust and social views conducted by Sandmo (2005), where the results of the study revealed that the views of friends, family or coworkers from taxpayers tend to influence a taxpayer to embezzle or not embezzle taxes . In general, Sandmo reports that the more people embezzle taxes, the more tax evasion is considered fair.

This research is a development of research conducted by Gustina (2016) entitled The Effects of Taxpayer Trust, Social Views and Taxation Systems on Tax Evasion Practices. The difference in this study with previous 
research is that this study uses a variable taxpayer trust, perceptions of justice and social views of the community, the authors add the variable perception of fairness in this study because the tax justice imposed by the government does affect the practice of tax evasion in society, while research previously using the variable Taxpayer Trust, and Social Views. This research was conducted in 2017 with different research locations so that this study is relevant to the taxation phenomenon that is happening in Indonesia.

B. Research Problems

This study will examine whether there is an influence of taxpayer trust, perceptions of fairness and social views of the community towards tax evasion. From the explanation above, several problems can be formulated as follows:

1. Is there influence on taxpayer's trust in the practice of tax evasion?

2. Is there an influence of social views on the practice of tax evasion.

C. Research Objectives and Contributions

1. The purpose of the study

a. To find out the influence and analyze the trust of taxpayers on the practice of tax evasion

b. To find out the influence and analyze the social view of the practice of tax evasion.

2. Research contributions

a. For Practical

For companies the results obtained in the study are expected to be a consideration

b. For Academics

This research is useful to be used as a reference for other writers if they want to do similar research.

\section{LITERATURE STUDY , LOGICAL FRAMEWORK, HYPOTHESIS}

\section{A. Literature Review}

In this literature review, the author will present theories related to the problem at hand. As the writer explained on the background of the previous problem, the problems that will be raised in this research are things that are pleasing to the tax evasion Starting from the general understanding to the understanding that focuses in detail on the theory relating to the problems that the author will examine.

1. Attribution Theory

Understanding attribution theory is a process in which individuals try to explain the reason for an event. Based on attribution theory, the causes that are perceived from a event and not the actual event itself affect people's behavior. More specifically, individuals will try to analyze why certain events arise and the results of these analyzes will affect their behavior in the future (Ivancevics 2005).

This attribution theory is very relevant to the purpose of this study because the willingness of taxpayers to pay taxes is related to the taxpayer's perception in assessing the tax itself. While a person's perception of a matter is influenced by internal and external factors of that person.

2. Definition of Fiscal Psychological Theory (Psychological Fiscal Theory)

Fiscal Psychological Theory states that the taxpayer's perception of the government is an important factor in tax compliance. Previously, most research on tax compliance was focused primarily on their own theories (McKerchar, 2001). Fiscal Psychological Theory was first introduced by Schmolders (1959) which links economics and behavioral approaches, where the study emphasizes that the low motivation of taxpayers to pay taxes is because taxpayers do not benefit from paying taxes. monetary form or public goods. This theory came to be known as fiscal psychological theory, which was also refined by Hasseldine and Bebbington (1991). The level of voluntary compliance of taxpayers is more influenced by the trust of taxpayers towards the government (Kogler d.k.k, 2013). Fiscal Psychological Theory provides better insight into the way people behave in economic situations by exploring the effects of economic issues and government actions on people's attitudes in an effort to encourage positive behavior in complying with tax regulations.

This Fiscal Psychological Theory is relevant to the purpose of this study because the taxpayer's willingness to pay taxes is influenced by the taxpayer's view of the tax itself. If taxpayers believe that the government has allocated taxes that they have paid well and that the existing taxation system is fair, then taxpayers will tend not to commit tax evasion.

3. Social Learning Theory (Social Learning Theory)

Understanding Social Learning Theory is learning that is done when someone observe and imitate the behavior of others (John W.Santrock 2008). The process by which information is obtained by observing events in the environment (Hergenhahn and Holson, 2008).

The relevance of social learning theory with the aim of this research is that someone will commit tax evasion if based on his experience and direct observation, the taxation system has not run effectively and fairly so that taxpayers will see that if in their environment other taxpayers tend to commit tax evasion and not detected by the tax authorities, the taxpayer will follow the behavior of other taxpayers so that the behavior of the tax evasion perpetrators will affect other taxpayers to carry out tax evasion. 
The taxpayer's perception of the government is important because the relationship between taxpayers and tax authorities is a contract that involves complex interactions between taxpayers and the government in building fair reciprocal relationships (Feld and Frey, 2002). In the tax compliance literature, perceptions about the fairness of the taxation system are known as one of the important factors that have a significant influence on tax compliance (Palil d.k.k, 2013).

Taxpayers tend to avoid taxes if they assume that the taxation system is unfair (Richardson, 2007). Saad (2009) proves that compared to the tax rate, the perception of taxes is more influential on tax compliance.

4. Taxpayer Trust

According to the Big Indonesian Dictionary, trust is defined as the belief that something is true or real. Trust in the government tends to increase the positive attitude of taxpayers and commitment to the system and payment of taxes, which will positively affect tax compliance. In addition, taxpayers will see taxes as prices that need to be paid for positive government actions so that they will trust the government more and be more honest.Taxpayers are very sensitive to how the government uses the taxes they have paid. There is a relationship between input and output between taxes that have been paid by taxpayers to the government and what taxpayers get from the government. Therefore taxpayer compliance can be influenced by benefits obtained from the government in the form of services and public goods. Taxpayers perceive their relationship with the government not only as a relationship of coercion but also as a relationship of mutual giving. Taxpayers will be more obedient to regulations if taxpayers feel the fairness between the taxes they have paid and their allocations.

Taxpayers are very sensitive to how the government uses the taxes they have paid. There is a relationship between input and output between taxes that have been paid by taxpayers to the government and what taxpayers get from the government. Therefore taxpayer compliance can be influenced by benefits obtained from the government in the form of services and public goods. Taxpayers perceive their relationship with the government not only as a relationship of coercion but also as a relationship of mutual giving. Taxpayers will be more obedient to regulations if taxpayers feel the fairness between the taxes they have paid and their allocations.

Relationships between individuals and government are considered psychological contracts that involve strong emotional ties and loyalty (Feld \& Frey 2002). Such psychological contracts can be maintained by positive actions based on trust in the government to increase incentives for individuals to commit to obey and comply with tax laws (Basri, 2013). The initial survey by Vogel (1974) in Sweden and Song \& Yarbrough (1978) in the US shows that individuals who have greater trust in government, they tend to avoid tax revenue fraud. Research conducted by Wearing \& Headey (1997) in Australia, and Slemrod (2003) in Germany and the US also supports a negative relationship between trust in the government and tax evasion. The results of the study of Kastlunger (2013) and Korgel (2013) show that trust relates to tax compliance and tax evasion (Basri, 2013). Van Dijke and Verbon (2010) examined the effect of moderating trust on the relationship of fairness and voluntary compliance and found that trust was important for increasing voluntary compliance when the authority focused on justice.

5. Community Social Views

Social views usually refer to the notion that someone follows the behavior of others (Ahmad 2009). Research reported by Lewis, Webley and Furnham (1995) found that if the government uses taxes paid to enrich itself, there will be a great reluctance from taxpayers to pay taxes. They think that taxes are better embezzled than being thrown away (corrupted by the government). In Indonesia, public confidence in the government tends to decline lately. TII Secretary General, Dadang Trisasongko stated that $65 \%$ of the Indonesian people considered that the government had not been serious in combating corruption. This figure according to Dadang has increased from the previous survey (Sutiono, 2015).

One of the causes of the practice of tax evasion based on research conducted by Ahmad (2014) in Pakistan is due to the behavior of other taxpayers who carry out tax evasion. "Go with the flow" usually refers to the meaning in which someone follows the attitudes and behavior of others. If the majority of people do things more often, then the rest will likely do the same. In this study, the attitude and behavior of a tax evasion perpetrator will affect the behavior of other taxpayers, as if the tax evasion perpetrators motivated other taxpayers not to pay taxes. Research on the practice of tax evasion was carried out by Sandmo (2005). Sandmo revealed that the views of friends, family, or coworkers from taxpayers tend to influence a taxpayer to embezzle or not embezzle taxes. In general, Sandmo reports that the more people embezzle taxes, the more tax evasion is considered fair. Although Sandmo conducted the research in Europe, these factors are still very relevant to be studied in Indonesia. One reason is that the Indonesian people are a very social type of population where norms and social assumptions often determine the decisions that individuals will make. In addition, tax evasion is increasingly considered common, especially among personal taxpayers. They will consider "normal" if there are friends who do not pay taxes.

6. Tax Evasion

Tax evasion is a business carried out by taxpayers to alleviate the tax burden by violating the law. Due to violating the law, this tax evasion is done using an illegal method. Taxpayers completely ignore the formal 
provisions of taxation which are their obligations, falsify documents, or fill data incompletely (According to Mardiasmo 2009). Tax evasion is an act of reducing taxes illegally. Research on the practice of tax evasion has been carried out by accountants, lawyers, economists and psychologists. Eric Posner (2000), a law professor who writes from a legal and economic perspective, states that most taxpayers are compliant with tax laws and thus, contrary to law enforcement of the economic standard model, which states that someone will violate the law if the benefits obtained are greater than the sanctions that will be received by KAP and incorrect.Barriers to tax collection, namely passive resistance and active resistance. Passive resistance where people are reluctant (passive) to pay taxes can be caused, among other things, intellectual and moral development of society, tax systems that (may) be difficult to understand and control systems cannot be carried out or implemented properly. Active resistance includes all efforts and actions that are directly addressed to the tax authorities with the aim of avoiding taxes, forms of tax evasion and tax avoidance. The most frequent form of tax resistance is tax evasion because it does not require higher fees and sufficient knowledge of the statutory regulations (Umar, 2013). The thing behind the action of tax evasion is usually because taxes are seen as a burden that will reduce one's economic capacity. They must set aside part of their income to pay taxes. Even if there is no tax obligation, the money paid for taxes can be used to increase the fulfillment of the necessities of life. It is not only companies (corporate taxpayers) that carry out tax evasion, even the average level of embezzlement of individual taxpayers is higher than mandatory.McGee (2006) suggests three views on tax evasion. The first three views are tax evasion as a behavior that is never ethical. Reasons that support this view include that every community has an obligation to its country to pay taxes. The second view is that tax evasion is seen as always ethical behavior, the reason being there is a widespread belief that there is no obligation to pay taxes to corrupt governments. The third view is that tax evasion is seen as sometimes ethical behavior. The reason for the third view is partly due to the view that there is no moral obligation to pay taxes to the state if the tax results in an increase in the price of goods for consumers, such as Value Added Tax (VAT). In addition, the reasons that support the view that tax evasion is sometimes ethical is if the government does not use the collected taxes to finance public expenditure such as the provision of public company tax facilities

7. Previous research

Previous research has become one of the authors' references in research so that the author can enrich the theory used in reviewing the research conducted.Ihsan Cemil Demir (2011) took the title of The Role of Selected Economic and Non-Economic Factors on Tac evasion Research locations in Turkey. In this study all variables were produced except social views had a significant negative effect on tax evasion. Robert McGee, Khaled Salmen A. and Anwar Salem M (2012) entitled The Ethics of Tax Evasion: A Survey of Administrative Sciences' Students in Yemen. Location of research in Yemen. In such research it results in ethical tax evasion when the taxation system is unfair, corrupt government, high tax rates and when taxes are levied are not used wisely or in the public interest. Gustina Salim (2016) takes the title Effect of Taxpayer Trust, Social Views and Taxation Systems on Tax Evasion Practices. The research resulted in simultaneous and partial that Taxpayer Trust, Social Views and Taxation System influenced the practice of tax evasion.

B. Conceptual \& Hypothesis Development

1. Effect of Taxpayers' Trust in Tax Evasion Practices.

Trust in tax authorities can be interpreted as trust in tax employees. The low level of trust of taxpayers on government apparatus arises because of the large amount of misuse of state money carried out by tax officials. Taxpayers are reluctant to pay taxes and many are cheating on the obligation to pay taxes because they assume that the money deposited for taxes is misused by the tax officials themselves.Based on the study of theory and previous research studies, the researchers concluded that the act of tax evasion by taxpayers can be influenced by the trust of taxpayers to the government because the higher and stronger the trust of taxpayers, the intention to tax evasion is decreasing, and vice versa.

H1: Trust must influence the practice of tax evasion.

2. Effects of the Society's Social View on the Practice of Tax Evasion

3. Based on the theory of Social Learning, one can learn through direct observation and experience. Someone will carry out tax evasion if based on their experience and direct observation, the taxation system has not run effectively and fairly so that taxpayers will see that if in their environment, other taxpayers tend to commit tax evasion and are not detected by tax authorities, the taxpayer will follow the behavior of other taxpayers so that the behavior of the tax evasion perpetrators will affect other taxpayers to carry out tax evasion In addition, if based on observations of taxpayers, the level of corruption committed by government officials has increased, then the trust of taxpayers to the government will decrease and cause taxpayers to start tax evasion because the taxes they have paid do not contribute significantly to general development or not allocated properly. Thus, tax evasion can be influenced by the social views of taxpayers on their environment because the more taxpayers are aware that other taxpayers also carry out tax evasion actions, the higher the tax evasion action. 
H2: Social views influence the view of tax evasion practices.

B. Research Hypothesis

On the basis of the above problems, the authors propose a hypothesis which is a temporary answer, where the hypothesis functions as a temporary guess. To measure precisely the extent to which the influence of taxpayer trust and social views on tax evasion practices carried out by taxpayers.

Based on the theories described earlier, the research hypothesis can be formulated as follows:

H1: Trust must influence the practice of tax evasion.

$\mathrm{H} 2$ : Social views influence the view of tax evasion practices.

\section{RESEARCH METHODS}

A. Time and Place of Research

The process of this research begins with activities to identify problems at the research site, conduct problem formulation, and collect basic theories to strengthen the theoretical foundation of each variable. Next is the preparation of methods in data collection, preparation of instruments to the testing techniques carried out, while the subjects used by researchers are Individual Taxpayers in the Kebayoran Lama Market. This research process requires time from January 2018 to May 2018.

B. Research Design

In this study researchers used a causal analysis method. Causal analysis is a causal relationship. Research conducted to find out about the effect of one or more independent variables (independent variables) on the dependent variable (dependent variable). Independent variable is a variable that affects or becomes the cause of change or the emergence of a dependent variable. The dependent variable is a variable that is influenced or which is a result of the existence of independent variables (Sugiyono, 2013).

The purpose of the causal research in this study was to find out how much influence the advertising, brand image and price of the decision to purchase Ades drinking water.

The approach taken in this study is a quantitative approach. According to Noor (2011), a quantitative approach is a method for testing certain theories by examining relationships between variables. These variables are measured usually by research instruments so that data consisting of numbers can be analyzed based on statistical procedures.

C. Measurement of Variables

Variable measurement is a tool used to qualify information provided by consumers if they are required to answer the questions formulated in a Noor questionnaire (2011). The measurement scale that the researcher uses in this study is using the Likert scale. Likert scale is a method used to measure attitudes, opinions and perceptions of a person or group of people about Sugiyono's social phenomenon (2013). The Likert scale instrument can be seen in Table 3.2 as follows:

\begin{tabular}{llcc}
\cline { 2 - 3 } Statement & code & Score \\
& Very agree & (SS) & 5 \\
& agree & (S) & 4 \\
& Netral & (N) & 3 \\
& Not agree & (TS) & 2 \\
D. Population and Study Samples & Very not agree & (STS) & 1 \\
\cline { 2 - 4 }
\end{tabular}

\section{Research Population}

According to Sugiyono (2013) the population is a generalization area consisting of objects or subjects that have certain qualities and characteristics set by researchers to be studied and then conclusions drawn.It can be concluded that the population is an observation carried out by researchers to find conclusions from the research population in this study is an Individual Taxpayer in the Kebayoran Lama Market.

2. Research Samples

Sugiyono (2012: 120) explains that the sample is part of the number and characteristics possessed by the population. From registered individual taxpayers (WP OP), the researcher determined 100 respondents to be sampled in this study. In this research the sampling technique used is accidental sampling technique. Accidental sampling is accidental sampling by taking a case or respondent who happens to exist or is available somewhere according to the research context (Notoatmodjo, 2010). This sampling method was chosen to facilitate researchers in conducting research on the grounds that the population to be studied is not and is not planned so that there is freedom of take the easiest and fastest sample with an estimate of the population in the same population in terms of what will be studied.

3. Data Collection Techniques

The data collection technique is the most important step in the research, because the main purpose of the research is to obtain data from Sugiyono (2013). Then the sample is taken because the members of the population met by the researcher and are willing to be respondents with consideration of the Individual Taxpayer 
in the Kebayoran Lama Market.

In this research the sampling technique used is accidental sampling technique. Accidental sampling is accidental sampling by taking a case or respondent who happens to exist or is available somewhere according to the research context (Notoatmodjo, 2010). In this study data was collected in two ways, namely (1) library research and (2) field research. Library research is conducted to collect data on theories that support research and other supporting data, while field research is conducted by collecting data from respondents. The field research data was carried out using questionnaires or questionnaires. The technique that uses a questionnaire is a way of collecting data by giving or distributing a list of questions to respondents. According to Noor (2011) the questionnaire is a technique of collecting data by giving or distributing a list of questions to respondents in the hope of providing a response to the list of questions. The list of questions is open and can be closed.

4.. Analysis Method

1. IBM SPSS Statistics 21

a) Descriptive Analysis (Desciptive Analysis)

Descriptive analysis is used to describe statistical data such as, minimum, maximum, mean, sum, standard deviation, variance, range, and so on. In addition, measuring the distribution of data with skewness and kurtosis (Priyatno, 2014). According to Sugiyono (2013) descriptive analysis is a statistic used to analyze data by describing or describing data that has been collected as it is without intending to make general conclusions or generalizations.

\section{ANALYSIS AND DISCUSSION}

\section{A.Overview}

The study used a questionnaire instrument or questionnaire that had been randomly distributed, with the object of research being an Individual Taxpayer who is in the scope of the Kebayoran Lama Market in South Jakarta.Samples were taken using the Accidental Sampling method. The sample of this study was 100 respondents from a total population of 10,520 who were in the scope of the Kebayoran Lama Market.

B. Characteristics of Questionnaire Answers

1. Characteristics of Descriptive Statistics Results

Descriptive statistics provide a description or description of a data that is seen from the average value (mean), standard deviation, variance, the maximum and minimum of each variable, namely trust in the government and social views of tax evasion. The description or description can be seen from the results that have been processed in Table 4.5 below

Based on Table 4.5 shows the number of respondents $(\mathrm{N})$ analyzed were as many as 100 respondents. The variable trust in the government has the lowest value of 2.70 and the highest value of 5.00 with a standard deviation (the level of distribution of data) of 4.44 .

The social view variable has the lowest value of 2.50 and the highest value of 4.00 with the standard deviation (the data distribution rate) of 3.26. While the overall variable of tax evasion practices has the lowest value of 2.0 and the highest value of 4.00 with a standard deviation (the level of distribution of data) of 3.60.

C. Data Analysis Method

Data Quality Test

1. Validity Test Results

Validity tests are used to measure the validity or validity of a questionnaire. A questionnaire is said to be valid if the question in the questionnaire is able to express something that will be measured by the questionnaire. Or in other words, validity wants to measure what the questions in the questionnaire that we have made can really measure what we want to measure

$$
\text { TABEL 4.6 }
$$

UJI VALIDITAS TERHADAP KEPERCAYAAN WAJIB PAJAK

\begin{tabular}{|c|c|c|c}
\hline Item Pertanyaan & $\begin{array}{c}\text { Person } \\
\text { Corelation }\end{array}$ & Sig.2 (tailed) & Keterangan \\
\hline P1 & 0,803 & 0,000 & Valid \\
\hline P2 & 0,889 & 0,000 & Valid \\
\hline P3 & 0,721 & 0,000 & Valid \\
\hline P4 & 0,878 & 0,000 & Valid \\
\hline P5 & 0,625 & 0,000 & Valid \\
\hline P6 & 0,781 & 0,000 & Valid \\
\hline P7 & 0,662 & 0,000 & Valid \\
\hline P8 & 0,781 & 0,000 & Valid \\
\hline P9 & 0,876 & 0,000 & Valid \\
\hline P10 & 0,848 & 0,000 & Valid \\
\hline
\end{tabular}

As showed on table 4.6, 4.7 and 4.8 there are correlation among others 
TABEL 4.7

UJI VALIDITAS TERHADAP PANDANGAN SOSIAL

\begin{tabular}{|c|c|c|c}
\hline Item Pertanyaan & $\begin{array}{c}\text { Person } \\
\text { Corelation }\end{array}$ & Sig.2 (tailed) & Keterangan \\
\hline P1 & 0,863 & 0,000 & Valid \\
\hline P2 & 0,874 & 0,000 & Valid \\
\hline P3 & 0,754 & 0,000 & Valid \\
\hline P4 & 0,763 & 0,000 & Valid \\
\hline P5 & 0,883 & 0,000 & Valid \\
\hline P6 & 0,853 & 0,000 & Valid \\
\hline P7 & 0,773 & 0,000 & Valid \\
\hline P8 & 0,693 & 0,000 & Valid \\
\hline P9 & 0,681 & 0,000 & Valid \\
\hline P10 & 0,741 & 0,000 & Valid \\
\hline \multicolumn{2}{l}{} \\
Sumber: Data Primer yang diolah menggunakan SPSS 21.0, 2018
\end{tabular}

the indicator for the total score of each variable shows significant results with the Pearson Correlation value $\geq$ 0.60 and has a significance level $<0.05$ and has a value of $r_{-}$count $>r_{-}$tabel. So, it can be concluded that each question indicator is valid.

2. Reliability Test Results

Reliability test is a tool to measure a questionnaire which is an indicator of a variable or construct. A questionnaire is said to be reliable or reliable if a person's answer to a statement is consistent or stable over time. The results of reliability testing using SPSS will produce Cronbach Alpha. A construct or variable is said to be reliable if it gives the Cronbach Alpha value $\geq 0.70$. Table 4.9 shows the reliability test results from four variables for 100 respondents.

TABEL 4.9

UJI REALIBILITAS

\begin{tabular}{|l|l|l|l|}
\hline No & Variable & Cronbach Alpha & $\begin{array}{l}\text { NOf } \\
\text { Items }\end{array}$ \\
\hline 1 & Kepercayaan kepada Pemerintah (X1) & 0,860 & 10 \\
\hline 2 & Pandangan Sosial (X2) & 0,765 & 10 \\
\hline 3 & Penggelapan Pajak (Y) & 0,755 & 10 \\
\hline
\end{tabular}

Based on Table 4.9 shows that all the question items which are indicators of each research variable both the dependent variable free mauvuvabel, have Cronbach Alpha values $\geq 0.70$ so it can be concluded that the respondents' answers to all variables are reliable.

2. Classical Assumption Test Results

a. Normality Test Results

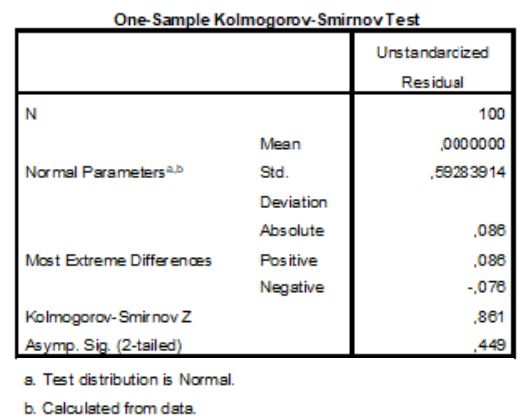

Based on Table 4.10 shows that the significance value for all variables $>0.05$ is 0.449 , then it can be based on Table 4.10

Its show that the significance value for all variables $>0.05$ is 0.449 , it can be concluded that the data are normally distributed or the regression model meets the normality assumption, it is concluded that the data is normally distributed or the regression model meets the assumptions of normality. In addition, the normality test can also be done with the P-Plot graph. Basic decision making for normality test with P-Plot graph is that data is said to be normally distributed when data spreads around. diagonal line or graph histogram.

b. Multicollinearity Test Results

The multicollinearity test aims to test whether the regression model is found to have a correlation between independent variables. A good regression model should not have a correlation between independent variables. To detect the presence or absence of multicollinearity in the regression model is to see the value of Tolerance and Variance Inflation Factor (VIF). If the tolerance value is $\leq 0.10$ or VIF $\geq 10$, it can be concluded that multicollinearity occurs. Table 4.11 shows the results of multicollinearity tests for all independent variables. 
TABEL 4.11

UJI MULTIKOLONIERITAS

\begin{tabular}{|c|c|c|c|c|c|c|}
\hline No & Variabel & \multicolumn{2}{|c|}{ Tolerance } & \multicolumn{2}{c|}{ VIF } & Keterangan \\
\cline { 3 - 6 } & & Regresi & Syarat & Regresi & Syarat & \\
\hline 1 & $\mathrm{X} 1$ & 0,995 & $\geq 0,10$ & 1,005 & $\leq 10$ & $\begin{array}{c}\text { Tidak } \\
\text { Multikolonieritas }\end{array}$ \\
\hline 2 & $\mathrm{X} 2$ & 0,995 & $\geq 0,10$ & 1,005 & $\leq 10$ & $\begin{array}{c}\text { Tidak } \\
\text { Multikolonieritas }\end{array}$ \\
\hline
\end{tabular}

c. Heterocedasticity Test Results

Heteroscedasticity test aims to test whether in the regression model there is an inequality of variance from the residual one observation to another observation. A good regression model is the Homoscedasticity (variance from residuals, one observation to another observation remains) or there is no heteroscedasticity. One way that is used to detect the presence or absence of heteroscedasticity is to use the Glejser test where Glejser proposes to reset the absolute value of the residual to the independent variable. If the statistically significant independent variables influence the dependent variable, there is an indication of heteroscedasticity. Table 4.12 shows the results of heteroscedasticity tests.

TABEL 4.12

UJI HETEROSKEDASTISITAS

\begin{tabular}{|l|r|r|r|r|r|}
\hline \multirow{2}{*}{ Model } & \multicolumn{2}{|l|}{ Unstandardized Coefficients } & $\begin{array}{r}\text { Standardized } \\
\text { Coefficients }\end{array}$ & \multirow{2}{*}{$\mathrm{t}$} & \multirow{2}{*}{ Sig. } \\
\cline { 2 - 5 } & \multicolumn{1}{|c|}{$\mathrm{B}$} & \multicolumn{1}{|c|}{ Std. Error } & \multicolumn{1}{c|}{ Beta } & & \\
\hline (Constant) &, 499 &, 423 & & 1,180 &, 241 \\
$\begin{array}{l}\text { Kepercayaan } \\
\text { Wajib Pajak }\end{array}$ &,- 003 &, 071 &,- 005 &,- 047 &, 963 \\
$\begin{array}{l}\text { Pandangan } \\
\text { Sosial } \\
\text { Masyarakat }\end{array}$ &, 006 &, 084 &, 007 &, 070 &, 944 \\
Sumber: Data primer diolah menggunakan SPSS 21.0 & & & \\
\hline
\end{tabular}

Based on Table 4.12, it is known that none of the independent variables statistically significant affect the dependent variable of Unstandardized Absolute Value (UAV). This can be seen from the probability of significance above the $5 \%$ confidence level, where for the trust variable has a significance of 0.963 the social view variable has a significance of 0.944 .

So it can be concluded that the regression model does not contain any heteroscedasticity.

3. Model Compatibility Test Results

4. Test the Hypothesi

TABEL 4.16

UJI SIGNIFIKANSI PARAMETER INDIVIDUAL (UJI STATISTIK T)

\begin{tabular}{|c|c|c|c|c|c|c|}
\hline \multirow[t]{2}{*}{ Mod } & & \multicolumn{2}{|c|}{$\begin{array}{l}\text { Unstandardized } \\
\text { Coefficients }\end{array}$} & \multirow{2}{*}{$\begin{array}{c}\text { Standardized } \\
\text { Coefficients } \\
\text { Beta } \\
\end{array}$} & \multirow[t]{2}{*}{$\mathrm{t}$} & \multirow[t]{2}{*}{ Sig. } \\
\hline & & B & Std. Error & & & \\
\hline \multirow{5}{*}{1} & (Constant) & 1,511 & 818 & & 1,847 & ,000 \\
\hline & Kepercayaan & 124 & 137 & ,091 & ,907 & ,010 \\
\hline & Wajib Pajak & & & & & \\
\hline & Pandangan Sosial & 260 & 162 & 160 & 1,601 & ,012 \\
\hline & Masyarakat & & & & & \\
\hline
\end{tabular}

a. Significant Test of Individual Parameters (T Test)

b.. Multiple Linear Analysis

Based on Table 4.16, it can be seen the regression equation for the influence of trust in government, and social views on the practice of tax evasion as follows:

$\mathrm{Y}=1,511-0,124 \mathrm{X} 1+0,260 \mathrm{X} 2+\mathrm{e}$

Where:

$\mathrm{Y}=$ Tax evasion practices

$\mathrm{X} 1=$ Trust in the government

$\mathrm{X} 2=$ Social views

$\mathrm{e}=$ Error tolerated

D. Discussion

Based on the description above, the discussion of the results of the study on the Effect of Trust in the Government and Social Views on Practice The normality test aims to test whether in the regression model, the 
residual confounding variable has a normal distribution. To test whether the data has a normal distribution or not is to use Colmogorof Semirnov. Data that is normally distributed is data that has a significance number $>5 \%$ (asymp sig $>5 \%$ ) then the regression model meets the assumptions of normality. The following table 4.10 shows the results of the normality test. Tax Evasion is as follows:

Influence of the Effect of Trust in the Government on Tax Evasion Practices.

Based on the research that has been done in Kebayoran Lama Market, the variable level of trust in the government has a significant level of 0.010 which means that the level of trust in the government has an effect on the practice of tax evasion because of the significant level of trust in the government. (2014), which states that simultaneously and partially the trust level factor

the government has an effect on tax evasion actions by taxpayers. This is possible because the perception of taxpayers will report on the case of the tax mafia and some cases of corruption lead to conflicts of trust of respondents as taxpayers of tax employees and government officials. If the taxpayer's trust in the government increases then

The practice of tax evasion will decline and result in increased tax revenues. This is in line with the research conducted by Yeni (2013) stating that the existence of trust in taxpayers with the government increases voluntary tax compliance and reduces tax evasion. In addition, the results of this study indicate similarities with the research reported by Mohd Ali (2013). Mohd Ali stated that when the community believed in the government's performance, the practice of tax evasion would tend to decline. Correspondingly, Ivanyna's research, Moumouras and Rangazas (2010), also stated that corrupt governance greatly influences the intention of citizens to pay taxes. Thus the disobedience of taxpayers in the scope of the Kebayoran Lama Market in paying taxes is also influenced by the low level of trust of taxpayers towards the government.

2. Effects of the Society's Social View on the Practice of Tax Evasion

Based on the results of hypothesis testing shows that the variable social outlook positively influences the practice of tax evasion, seen from the significant level of 0.012 (less than 0.05 ) and $t$ count smaller than $t$ table. This indicates that the social outlook is getting higher, it will affect the practice of tax evasion significantly. These findings are in line with the research reported by Maria (2014), which states that simultaneously and partially social factors influence tax evasion by taxpayers. This finding is also in accordance with previous research conducted by Demir (2011) by taking samples of taxpayers in Turkey.

Karlinsky, et al. (2014) also reported the same results that one's intention to embezzle taxes was influenced by social views. The results of this study also further support the validity of the social learning theory described by Bandura (2014). Bandura states that one can learn through direct observation and experience, so that if the majority of the public embezzles taxes it will affect taxpayers in the community to further embezzle taxes.

\section{CONCLUSIONS AND SUGGESTIONS}

A.Conclusion

This study aims to determine the effect of Taxpayer Trust and the Society's Social View on Tax Evasion. The respondents of this study were 100 individual taxpayers who were in the Kebayoran Lama Market. Based on the data that has been collected and the tests that have been carried out on the problem, it can be concluded as follows: From the results of the discussion and data analysis in the previous chapter the variables of environmental advertising have a significant effect on the purchasing decisions of bottled water in Ades. This is indicated by the $t$-value of 5.253 which is greater than $t$ table of 1.96 , which means that the purchasing decision can be influenced by one of them is the go green factor with product innovation that is environmentally friendly and invites the public to care. environment. The trust of taxpayers to the government has a significant negative effect on the practice of tax evasion. This proves that the lower the level of trust in the taxpayer, the more it increases the practice of tax evasion.

In this study shows that social views have a significant positive effect on the practice of tax evasion. This proves that the higher the social outlook, the more it increases the practice of tax evasion.

B. Implications

There are several implications or limitations in this study, namely:

1. The chosen observation area is a market area, making people sometimes reluctant to fill out questionnaires and take a long time to make the research stagnate.

2. The research sample only focuses on Individual Taxpayers who are in the market scope of Kebayoran Lama and do not enter the due corporate taxpayer

Tax reporting for Corporate Taxpayers is represented by company couriers.

C. Suggestion

Based on the results of the analysis and discussion that has been explained and the conclusions that have been described previously, the researcher wants to give some suggestions that can be used as material input or consideration for interested parties as follows:

1. Directorate General of Taxes 
The government as the highest institution mandated to manage existing tax funds must further improve performance, quality, quality, discipline and integrity that are related to the morals demanded by each Directorate General of Taxes by being honest and clean from despicable actions and always prioritizing interests Country.

2.Government

The government must be better at monitoring, accommodating, distributing and processing existing tax funds, so that taxpayers become happy and have a high level of awareness of voluntary tax compliance. Because of this, the target of state tax revenues can increase in order to create equitable national development.

3. Taxpayers

Taxpayers as parties who pay taxes should be aware of their obligations in paying taxes with honesty and have a great sense of responsibility for the trust given in calculating, recording, paying and reporting taxes owed.

4. Other researchers

Before conducting the research, the next researcher is expected to determine in advance the research observation site so that the compiled research runs smoothly and on time.

\section{REFERENCES}

Agnar Sandmo. (2005). The Theory of Tax Evasion: A Retrospective View. National Tax Journal, Vol LVIII, No.4 December 2005.

Agus Nugroho Jatmiko. (2006). Pengaruh Sikap Wajib Pajak dan Pelaksanaan Sanksi Denda, Pelayanan Fiskus dan Kesadaran Perpajakan terhadap Kepatuhan Wajib Pajak. Tesis. Program Studi Magister Akuntansi Universitas Diponegoro.

Angelina, Maria dan Yenni. (2014). "Pengaruh Pandangan Sosial, Usia, dan Kepercayaan Kepada Pemerintah Terhadap Praktik Penggelapan Pajak di Surabaya”. Jurnal Tax \& Accounting Review, Universitas Kristen Petra, Vol 4, No1.

Ardyaksa, Theo dan Kiswanto. (2014). "Pengaruh Keadilan, Tarif Pajak,Ketepatan Pengalokasian, Kecurangan, Teknologi dan Informasi Perpajakan terhadapTax Evasion”. Accounting Analysis Journal, Unniversitas Negri Semarang,Vol 3 No.4

Benk, Serka7n dkk. (2015). "Perception of tax evesion as a crime in Turkey".Jurnal of Money Laundering, Unniversitas of Queensland,Vol 18 No 1.

Demir, Ihsan Cemil. (2011). The Role Of Selected Economic and Non-Economic Factors on Tax Evasion : An Empirical Inspection.

Devi Nur Cahya Ningsih dan Devy Pusposari. (2015). Determinan Persepsi Mengenai Etika atas penggelapan Pajak (Tax Evasion). Jurnal Ilmiah Mahasiswa FEB, Vol.3, No.1.

Direktorat Jendral Pajak Kementrian Keuangan. Pengertian Tax Amnesty: Amnesty Pajak 2016. Diakses dari http://www.lembagapajak.com/2016/07pengertian-pengampunan-pajak-tax-amnesty-adalah.html tanggal 11 September 2016.

Elmiza, Mesri dkk. (2014). "Pengaruh Keadilan, Sistem Perpajakan dan Diskiminasi Terhadap Presepsi Wajib Pajak Mengenai Etika Penggelapan Pajak (Tax Evasion)”. E-Journal Universitas Bung Hatta, Jakarta, Vol 4 No 1

Enste, H. Dominik \& Schendik, Frederick, Shadow Economies: Size, Causes and Consequences, Journal of Economic Literature, Vol. XXXVIII March 2000, pp 77-114

Erly Suandy.(2008). Perencanaan Pajak, Ed 4. Jakarta : Salemba Empat.

Ghozali, I. (2009). Aplikasi Analisis Multivariate dengan Program SPSS. Semarang: Badan Penerbit Universitas Diponegoro.

Hammar, H., S. C. Jagers., dan K.Nordblom. (2005). "Tax Evasion and the Importance of Trust". Working Paper in Economic, Swedia, no. 179.

Harold Kelley.(1973). The Process of Causal Attribution. American Psychologist February 1973

Huslin, Daniel dan Ngadiman. (2011). Pengaruh Sunset Policy, Tax Amnesty, dan Sanksi Pajak Terhadap Kepatuhan Wajib Pajak. Jurnal Akuntansi. Vol XIX, No.02, Mei 2015:225-241.

Imelda, Bona. (2014). "Analisa Faktor-Faktor Yang Mempengaruhi Kepatuhan Wajib Pajak Orang Pribadi (Studi PAda Kantor Pelayanan Pajak Pratama Semarang)”. Skripsi.Semarang: Fakultas Ekonomi dan Bisnis Universitas Diponegoro.

Ivanyna, Maksym, Alexandros Mourmoras and Peter Rangazas. (2010). The Culture of Corruption, Tax Evasion and Optimal Tax Policy. International Monetary Fund WP/10/xx.

Mardiasmo.(2011). Perpajakan Edisi Revisi 2011. Yogyakarta: Penerbit Andi.

Maria Angelia Sutiono dan Yenni Mangoting. (2014). Pengaruh Pandangan, Usia dan Kepercayaan kepada Pemerintah terhadap Praktik Penggelapan Pajak di Surabaya. Tax and Accounting Review, Vol.4, No.1.

Marina.(2015). Pengaruh Risiko Persepsian dan Risiko Kinerja terhadap Intensi Mengadopsi e-Filling. Skripsi. Fakultas Ekonomi dan Bisnis Universitas Mercu Buana. 
McGee, Robert W dkk. (2008). “ A Comparative Study on Perceived Ethics of Tax Evasion: Hong Kong vs the United States". Journal of Business Ethics, no 77.

McGee, Robert dkk. 2009. " Presenting the Dimensionality of An Ethics Scale pertaining to Tax Evasion ". Journal of Legal, Ethical and Regulatory Issues, 23

Mughal, Muhammad Muazzam and Muhammad Akram. (2014). Reasons of Tax Avoidance and Tax Evasion: Reflections from Pakistan. Journal of Economics and Behavioral Studies Vol. 4 No. 4

Nazaruddin, Ietje dan Agus Tri (2016).Analisis Statistik dengan SPSS. Yogyakarta: Danisa Media

Rachmadi, Wahyu. (2014). “Faktor-Faktor Yang Mempengaruhi Persepsi Wajib Pajak Orang Pribadi Atas Perilaku Penggelapan Pajak (Studi Empiris Pada Wajib Pajak Terrdaftar di KPP Pratama Semarang Candsari)”. Skripsi.Universitas Diponegoro.

Rahman, I. S. (2013). "Pengaruh Keadilan, Sistem Perpajakan, Diskriminasi, dan Kemungkinan Terdeteksinya Kecurangan Terhadap Persepsi Wajib Pajak Mengenai Etika Penggelapan Pajak (Tax Evasion)”.Skripsi. Jakarta: Fakultas Ekonomi dan Bisnis Universitas Islam Negeri Syarif Hidayatullah.

Salim, Gustina. (2016). "Pengaruh Kepercayaan Wajib Pajak, Pandangan Sosial Masyarakat, dan Sistem Perpajakan tehadap Praktik Penggelapan Pajak. Skripsi. Program Studi Akuntansi Universitas Mercubuana.

Santoso, Urip \& Justina, Setiawan.(2009) Tax amnesty dan Pelaksanaanya di Beberapa Negara : Perspektif Bagi Pebisnis Indonesia, Kopertis, Volume 11 No. 2.

Siahan, Marihot P. (2010). Hukum Pajak Elementer.Yogyakarta. Penerbit: Graha Ilmu.

Suminarsasi, W. dan Supriyadi. (2011). “Pengaruh Keadilan, Sistem Perpajakan,dan Diskriminasi Terhadap Persepsi Wajib Pajak Mengenai Etika Penggelapan Pajak (Tax Evasion)”. Thesis. Yogyakarta: Universitas Gadjah Mada.

Tarmidi Deden, Waluyo TEKUN: Jurnal

Telaah Akuntansi dan Bisnis 2014,Faktor-Faktor yang Mempengaruhi Kepatuhan Pajak, Dengan Pendekatan Perilaku dan Etika (Studi Empiris Pada Perusahaan PMA Yang Terdaftar Di Kanwil DJP Jakarta Khusus)

Theresia Woro Damayanti, dkk.(2015). The Role of Taxpayer's Perception of the Government and Society to Improve Tax Compliance. Accounting and Financial Research. Vol. 4, No. 1.

Undang - Undang Republik Indonesia Nomor 11 Tahun 2016 Tentang Pengampunan Pajak. Diakses dari http:www.jdih.kemenkeu.go.id/fullText/2016/11TAHUN20 16.pdf

Wicaksono, Muhammad. (2014). "Pengaruh Persepsi Sistem Perpajakan, Keadilan Pajak, Diskriminasi Pajak Dan Pemahaman Perpajakan Terhadap Perilaku Penggelapan Pajak (Studi Empiris Pada Wajib Pajak Orang Pribadi Terdaftar Di Kpp Pratama Purworejo)”.'Skripsi.Universitas Diponegoro Semarang: 2012. Tidak dipublikasikan.

Widarto, Edwin. (2013). “ Faktor-Faktor Yang Mempengaruhi Kemauan Untuk Membayar Pajak Pada Usaha Kecil dan Menengah (UKM) Di Surabaya. Tesis.Fakultas Bisnis Universitas Katolik Widya Mandala. 